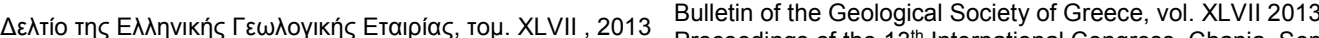

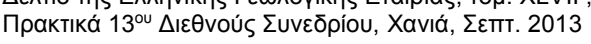

\title{
STABILIZATION OF THE LIMESTONE ESCARPMENT OF THE SKETE OF OSIOS NIKANORAS UNDER WET CONDITIONS DUE TO FUTURE FILLING OF THE ILARION DAM'S RESERVOIR
}

\author{
Mourtzas N.D. ${ }^{1}$, Gkiolas A. ${ }^{2}$ and Kolaiti E. ${ }^{1}$ \\ ${ }^{I}$ GAIAERGON Ltd, Kefallinias Str.16-18, 15231 Chalandri, Athens, gaiaergon@gmail.com \\ ${ }^{2}$ Civil Engineer, 15 Hydras Str, 104 34, Athens, agkiolas@gmail.com
}

\begin{abstract}
The Skete of Osios Nikanoras is located in a cavern of a vertical limestone escarpment $80 \mathrm{~m}$ high, over Aliakmon River in West Macedonia. The vertical slope is structured predominantly of thick-bedded limestone, dipping moderately towards $N W$ and only locally of thin-bedded limestone. It is crossed by three transverse and four normal faults. Rock mass was divided in sections, demarcated by bedding planes and major discontinuities. Each section was subdivided into rock blocks. Rock mass description was carried out in areas below the entrance level and the surrounding areas of the Skete as well.

The future water level rise, due to the filling of the Ilarion Dam's reservoir, followed by water level fluctuations, will impose an initial increase and a subsequent variation of water pressures in the rock mass discontinuities. The evaluation of the rock mass stability, due to water induced loads, was therefore required. Stability analysis has been performed in order to determine potential wedge, plane and toppling failure modes.

The measures that were adopted for the conservation of the monument were designed taking into account the restrictions regarding the monuments preservation. The proposed solution comprised three stages of installation of support measures, namely, installation of temporary rock bolts for the pre-strengthening of the rock mass, followed by the execution of grouting and finally installation of permanent rock anchors, thus ensuring adequate factors of safety.
\end{abstract}

Key words: engineering geology; rock mass description;stability analysis;support measures.

\section{Пєрі́⿱ $\eta \psi \eta$}

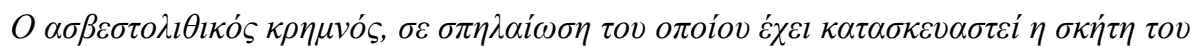

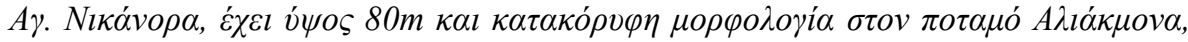

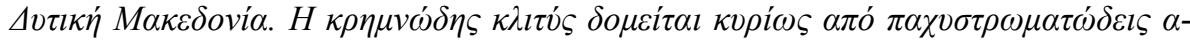

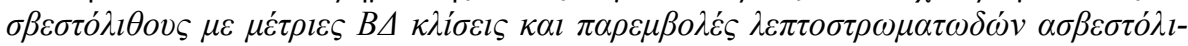

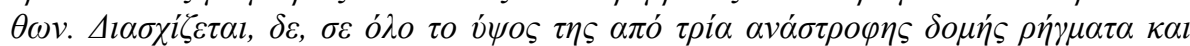

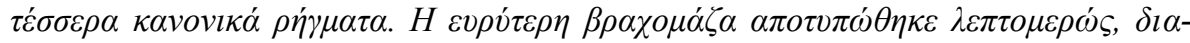

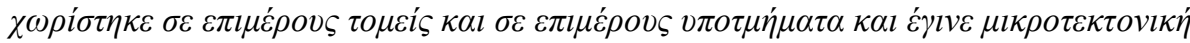

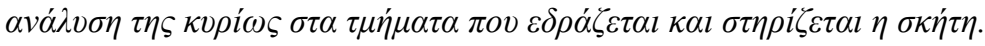

$\underline{\text { XLVII, No } 3-1779}$ 


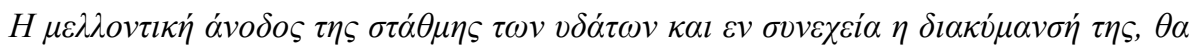

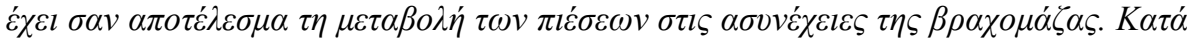

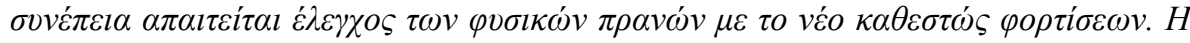

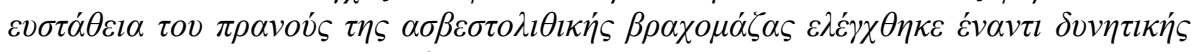

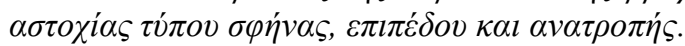

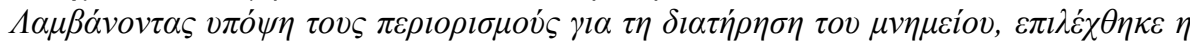

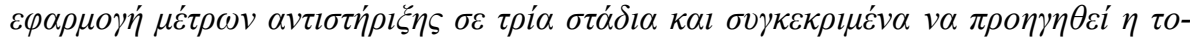

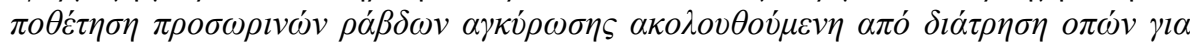

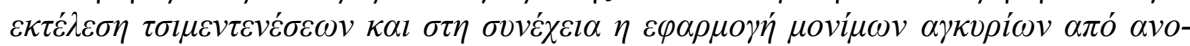

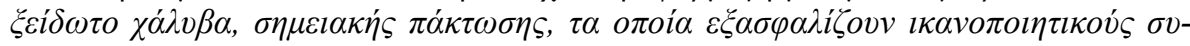
$v \tau \varepsilon \lambda \varepsilon \sigma \tau \varepsilon \dot{\varsigma} \alpha \sigma \varphi \alpha \lambda \varepsilon i \alpha \varsigma$.

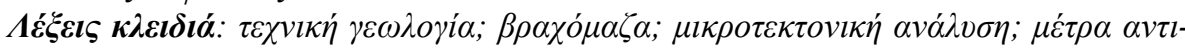

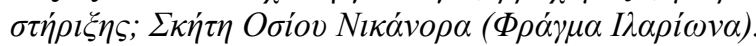

\section{Introduction}

The scattered archaeological and historical monuments throughout the Greek territory are, usually, exposed to physical processes, in different climatic, topographical and geological conditions. Therefore, they are subject to weathering of their structural features, modification of the initial bearing capacity of foundation, erosion mainly due to uncontrolled discharge of surface water drainage, groundwater activity, earthquake loading in an active geotectonic environment, and human interventions.

The Skete of Osios Nikanoras is located on the sheer northern slope of Aliakmonas River, at the southern foothills of Mt. Kallistrato (Figure 1). The construction of the Skete begun in 964 AD by Monk Georgios and was completed by Osios Nikanoras, who followed an ascetic life on the sacred rock for 15 years.

Due to the construction of Ilarion hydroelectric project at the Aliakmonas River in Kozani prefecture, and the future filling of the Ilarion dam's reservoir, the base of the Skete will be located near the uppermost water level of the artificial lake. The ensuring of the surrounding rock mass stability and the support of the monument's slopes were therefore required, as the Skete will be directly affected by the operation of the dam, taking into account the restrictions regarding the monuments preservation as specified by the Greek Ministry of Culture. The project was financed and supervised by the Public Power Corporation SA.Due to the steep relief of the project area and the difficulty to access parts of the Skete's slope in order to acquire a detailed documentation of the rock mass fracturing and the engineering geological conditions of the vertical limestone escarpment, a 3D surface model of the rock mass deriving from 3D laser Scanning, was produced. The rock mass has been recorded using a Trimple GX200Plus terrestrial laser scanner at a resolution of $1 \mathrm{~cm}$.

\section{Geological Outlines}

\subsection{Geomorphological Context}

Mt. Kallistrato forms a conical steep foothill at the SW edge of the Vourinos Mountain. A deep, semicircular gorge, at a curve of Aliakmon River just before it follows a NE direction towards Serbia area, separates Vourino Mountain from Vounasa Mountain which develops to the South (Figure 1).

The Aliakmon's river bed develops along the gorge formed between Mt Kallistarto to the North and Petrota area to the South, bypassing Mt Kallistrato with a semicircular clockwise curve. The right bank is $124 \mathrm{~m}$ high and the left one $100 \mathrm{~m}$, with steep morphological inclinations of $70^{\circ}$ approx. The Skete of Osios Nikanoras has been built in a cavern of the limestone escarpment which 


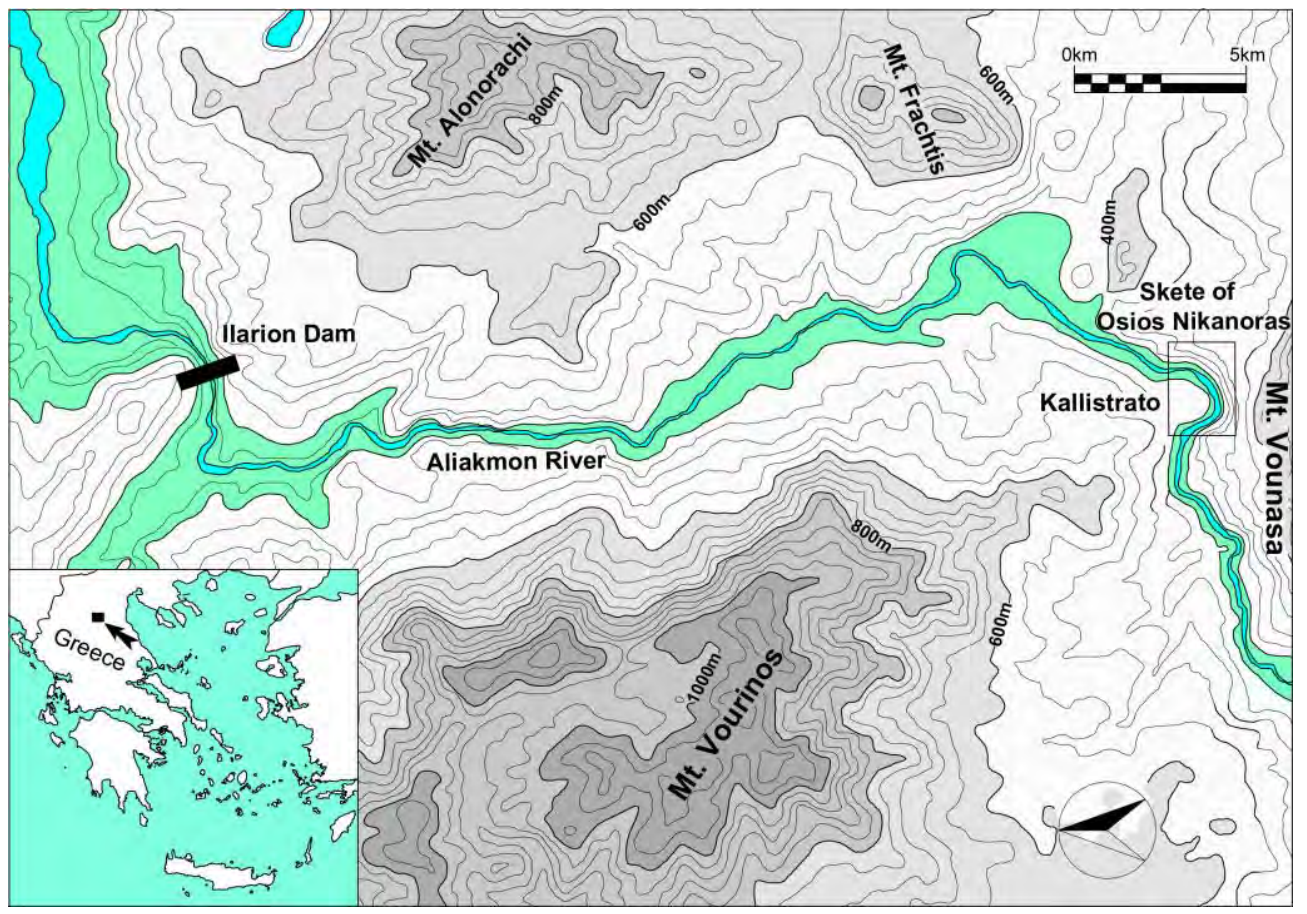

Figure 1 - Location map of the wider area of the Skete of Osios Nikanoras and Ilarion Dam.

develops in WNW-ESE direction and inclines towards SE, at elevation that ranges from $450 \mathrm{~m}$ to $360 \mathrm{~m}$ asl, forming the western section of the southern slope of Mt. Kallistrato. It has a length of $274 \mathrm{~m}$, a height of $80 \mathrm{~m}$ and very steep gradients (inclinations ca $80^{\circ}$ ). Its surface is almost planar with caverns and cavities, mainly along the tectonic zones and major discontinuities of the rock mass. The relief becomes smoother at the base of the escarpment, where the semi-metamorphic schist bedrock appears, beneath the elevation of $360 \mathrm{~m}$ asl and up to the river bed, with reduction of morphological gradients to $35^{\circ}$, dipping to the SW (Figure 2).

The cavern of the Skete is formed by a fault surface with NW-SE direction and almost vertical inclination to the SW in its eastern side, a major discontinuity with NW-SE direction dipping almost vertically to the NE in the northern side and the limestone layer on the roof, which inclines to the NW at angle of $40^{\circ}$. The cavern with almost vertical side walls has dimensions of $25 \mathrm{~m}$ by $7 \mathrm{~m}$, a height of $21 \mathrm{~m}$ and an area of $450 \mathrm{~m}^{2}$ (Figure 2).

\subsection{Geological Structure}

The pre-alpine metamorphic bedrock of the Pelagonian zone consists of Paleozoic gneiss-schists and mica schists, the Triassic marbles of Vounasa-Tranovaltos, phyllites of the Early Jurassic, ophiolithes of the Middle and Late Jurassic, and limestones of the Late Jurassic-Cretaceous (Vérgely, 1984; Katsikatsos, 1992; Karapantelakis, 2008).

Mt. Kallistrato is formed by partially crystallized, thickly bedded, light coloured limestones of the Middle Triassic - Jurassic with interpolations of thinly-bedded strata. They are, actually, the normal upward evolution of the Palaeozoic - Early Triassic semi-metamorphic rocks of the Pelagonian zone. The Middle Triassic - Jurassic schists are the bedrock of the calcareous mass and appear at the base of the escarpment, with bedding and schistosity planes dipping smoothly towards NW.

The sheer slope is structured mainly by thickly bedded limestones, with thickness of bedding that ranges from $1.60 \mathrm{~m}$ to $3.0 \mathrm{~m}$, and dip direction to the $\mathrm{NW}$, at angles between $30^{\circ}$ and $40^{\circ}$. Two horizontal layers, $7.0 \mathrm{~m}$ thick, of thinly-bedded limestones with thickness of bedding that ranges from 
$0.02 \mathrm{~m}$ to $0.10 \mathrm{~m}$ come between; with their continuity and thickness interrupted and transformed among the faults which cross the limestone mass (Figure 2).

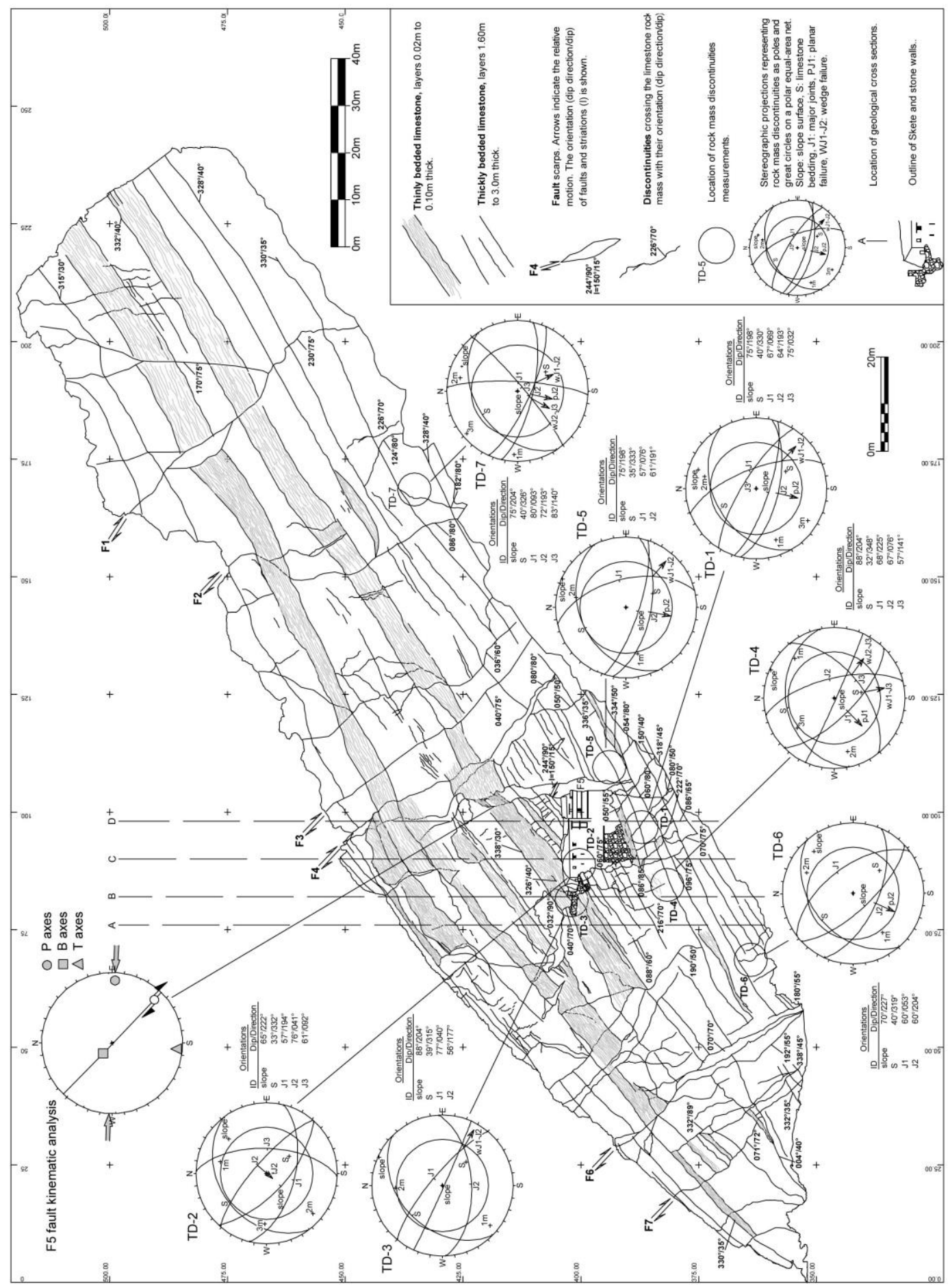

Figure 2 - Geological and tectonic map of the slope face. 


\subsection{Tectonic Setting}

Three reverse faults (F1, F5 and F6) and four normal faults (F2, F3, F4 and F7) which have caused the interruption in continuity and the displacement of the limestone layers cross the entire, calcareous, sheer slope (Figure 2). The westernmost fault F1, with its trace at the upper and lower part of the slope at elevations $496 \mathrm{~m}$ and $447 \mathrm{~m}$, respectively, dips to the $\mathrm{SW}$ at angle of $75^{\circ}$ and it has caused a small upward displacement of its western block by ca. $1 \mathrm{~m}$. The next downward fault F2, with its trace $475 \mathrm{~m}$ and $426 \mathrm{~m}$ in elevation, dips to the ENE at an angle of $80^{\circ}$ and it has, also, caused a small downward movement of its eastern block. Fault F3, with its trace $454 \mathrm{~m}$ and $410 \mathrm{~m}$ in elevation, dips to the NE at an angle of $75^{\circ}$ and has given rise to a downward displacement along the eastern block by $2 \mathrm{~m}$. The following fault F4, with its trace at elevations $450 \mathrm{~m}$ and $405 \mathrm{~m}$, dips to the ENE at an angle of $80^{\circ}$ and it has caused downward movement of its eastern block by $5.50 \mathrm{~m}$ approx. The F5 fault, with its trace $450 \mathrm{~m}$ and $389 \mathrm{~m}$ in elevation, dips almost vertically to the SW and it has given rise to an upward displacement of its western block by $2 \mathrm{~m}$. The striations on the fault slip surface dip to the SE at an angle of $15^{\circ}$ referring to a compressive event of a WNW-ESE direction (Figure 2). Finally, faults F6 and F7, at the eastern end of the sheer slope, with their traces at elevations $450 \mathrm{~m}, 389 \mathrm{~m}$ and $380 \mathrm{~m}, 350 \mathrm{~m}$, respectively, dip to the NE at an angle of $70^{\circ}$ and they have caused the interruption in the continuity and the displacement of the layers (Figure 2, Figure 3).

\subsection{Seismicity and Seismic Hazard}

The wider area of Ilarion dam is characterized by medium seismic hazard. The most important historical earthquakes, which hit the greater area of the Skete of Osios Nikanoras the period between 375AD and 1646AD, were three events with estimated magnitudes of 6.0 up to 7.3 (Papazachos and Papazachou, 1989). There are not records for earthquakes of magnitude greater than or equal to 7.0 in the study area for the same time period. The area belongs to the seismic zone II of the revised Seismic Hazard Map, provided by the modified Greek Antiseismic Regulations (EAK, 2000). In this zone the value of ground acceleration is $A=0.24 \mathrm{~g}$ (g: gravity acceleration), with a ten percent $(10 \%)$ probability of exceedance in fifty years. According to the aforementioned Regulations (EAK, 2000), the limestone rock mass is classified as soil category A.

\section{Quantitative Description of Discontinuities in the Rock Mass}

In order to evaluate the engineering geological conditions and to determine the rock mass properties, discontinuities were investigated and data was collected at seven (7) areas throughout the Skete's slope. The data were selected on the basis of support requirements mainly in the rock mass sections where the Skete is founded (Figure 2) (Hoek and Brown, 1981; ISRM Suggested Methods, 1981). It was concluded that the rock mass fragmentation is, mainly, due to four discontinuity sets, with dominant discontinuity the limestone bedding with a NE-SW direction and a smooth dip towards NW. Three major joint sets of NW-SE, WNW-ESE and NE-SW directions dipping to the NE, SSW and SE, respectively, are also developed in the rock mass. The quantitative description of discontinuities according to ISRM (1981) is presented in Table 1. Stereographic projections for each selected area representing discontinuities as poles and great circles on a polar equal-area net were plotted and are presented in Figure 2.

\section{Potential Slope Failure Modes}

Kinematic analysis has been performed to determine potential failure modes utilizing stereographic projection technique and data for each selected area, based on the methods designated to evaluate the possibility of wedge, plane and toppling failure modes (Markland, 1972; Hocking, 1976; Goodman, 1976; Hoek and Bray, 1981; Matherson, 1988). Rocky blocks kinematically feasible in relation to the geometry (dip direction/dip) of the slope face, were 
identified, assuming that the mean value of the friction angle of all discontinuities in the limestone rock mass is $35^{\circ}$. The sliding potential and modes of failure are presented in Table 2.

Table 1 - Classification of discontinuity sets according to ISRM (1981).

\begin{tabular}{|c|c|c|c|c|c|c|c|c|c|c|c|c|c|}
\hline \multirow[b]{2}{*}{ 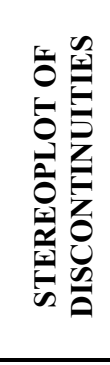 } & \multirow[b]{2}{*}{ 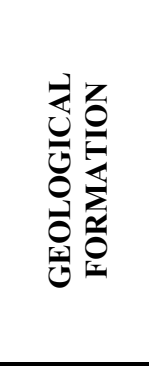 } & \multirow[b]{2}{*}{ 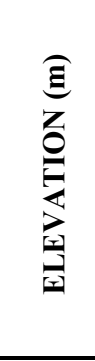 } & \multicolumn{3}{|c|}{$\begin{array}{c}\text { DISCONTINUITY } \\
\text { SETS }\end{array}$} & \multirow[b]{2}{*}{ 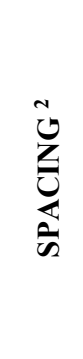 } & \multirow[b]{2}{*}{ 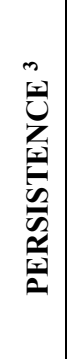 } & \multirow[b]{2}{*}{ 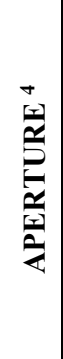 } & \multirow[b]{2}{*}{ 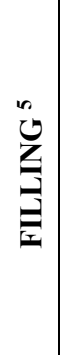 } & \multirow[b]{2}{*}{ 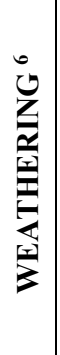 } & \multirow[b]{2}{*}{$\begin{array}{l}n \\
0 \\
0 \\
0 \\
0 \\
0 \\
0 \\
0 \\
0\end{array}$} & \multirow[b]{2}{*}{ 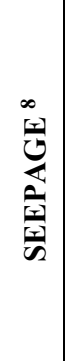 } & \multirow[b]{2}{*}{ 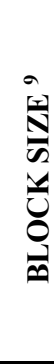 } \\
\hline & & & 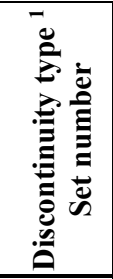 & 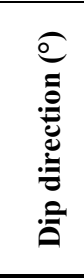 & $\begin{array}{l}\text { ఠ } \\
\stackrel{\tilde{\theta}}{\underline{\theta}}\end{array}$ & & & & & & & & \\
\hline \multirow{4}{*}{ TD-1 } & \multirow{4}{*}{$\begin{array}{l}\text { thick and } \\
\text { thin bed- } \\
\text { ded lime- } \\
\text { stone }\end{array}$} & \multirow{4}{*}{+387} & $\mathbf{S}$ & 330 & 40 & $\mathrm{~d}, \mathrm{f}$ & $\mathrm{e}$ & $\mathrm{a}$ & $\mathrm{O}$ & I & VIII & III & \multirow{3}{*}{$\mathrm{a}$} \\
\hline & & & J1 & 69 & 67 & $\mathrm{e}, \mathrm{f}, \mathrm{g}$ & $\mathrm{d}, \mathrm{e}$ & $\mathrm{b}, \mathrm{c}$ & $\mathrm{O}$ & $\mathrm{I}$ & $\mathrm{V}$ & III & \\
\hline & & & $\mathrm{J} 2$ & 193 & 64 & $e, f, g$ & $\mathrm{~d}, \mathrm{e}$ & $\mathrm{b}, \mathrm{c}$ & $\mathrm{O}$ & $\mathrm{I}$ & $\mathrm{V}$ & III & \\
\hline & & & $\mathrm{J} 3$ & 32 & 75 & $\mathrm{e}, \mathrm{f}, \mathrm{g}$ & $\mathrm{d}, \mathrm{e}$ & $\mathrm{b}, \mathrm{c}$ & $\mathrm{O}$ & I & $\mathrm{V}$ & III & $\mathrm{b}$ \\
\hline \multirow{4}{*}{ TD-2 } & \multirow{4}{*}{$\begin{array}{l}\text { thick and } \\
\text { thin bed- } \\
\text { ded lime- } \\
\text { stone }\end{array}$} & \multirow{4}{*}{+400} & $\mathbf{S}$ & 332 & 33 & $\mathrm{~d}, \mathrm{f}, \mathrm{g}$ & $\mathrm{e}$ & $\mathrm{a}$ & $\mathrm{O}$ & $\mathrm{I}$ & VIII & III & \multirow{4}{*}{$\mathrm{a}$} \\
\hline & & & J1 & 194 & 57 & $\mathrm{e}, \mathrm{f}, \mathrm{g}$ & $\mathrm{d}, \mathrm{e}$ & $\mathrm{b}, \mathrm{c}$ & $\mathrm{O}$ & I & $\mathrm{V}$ & III & \\
\hline & & & $\mathrm{J} 2$ & 41 & 76 & e,f,g & $\mathrm{d}$ & $\mathrm{b}, \mathrm{c}$ & $\mathrm{O}$ & $\mathrm{I}$ & $\mathrm{V}$ & III & \\
\hline & & & $\mathrm{J} 3$ & 92 & 61 & $\mathrm{e}, \mathrm{f}, \mathrm{g}$ & $\mathrm{d}$ & $\mathrm{b}, \mathrm{c}$ & $\mathrm{O}$ & I & $\mathrm{V}$ & III & \\
\hline \multirow{3}{*}{ TD-3 } & \multirow{3}{*}{$\begin{array}{c}\text { thin } \\
\text { bedded } \\
\text { limestone }\end{array}$} & \multirow{3}{*}{+400} & $\mathbf{S}$ & 315 & 39 & $\mathrm{~d}$ & $\mathrm{e}$ & $\mathrm{a}$ & $\mathrm{O}$ & $\mathrm{I}$ & VIII & III & \multirow[t]{3}{*}{ d } \\
\hline & & & J1 & 40 & 77 & $e, f, g$ & $\mathrm{~d}, \mathrm{e}$ & $\mathrm{b}, \mathrm{c}$ & $\mathrm{O}$ & I & $\mathrm{V}$ & III & \\
\hline & & & $\mathrm{J} 2$ & 177 & 56 & $\mathrm{e}, \mathrm{f}, \mathrm{g}$ & $\mathrm{d}, \mathrm{e}$ & $\mathrm{b}, \mathrm{c}$ & $\mathrm{O}$ & I & $\mathrm{V}$ & III & \\
\hline \multirow{4}{*}{ TD-4 } & \multirow{4}{*}{$\begin{array}{l}\text { thick and } \\
\text { thin bed- } \\
\text { ded lime- } \\
\text { stone }\end{array}$} & \multirow{4}{*}{+382} & $\mathbf{S}$ & 348 & 32 & $\mathrm{~d}, \mathrm{f}$ & $\mathrm{e}$ & $\mathrm{a}$ & $\mathrm{O}$ & $\mathrm{I}$ & VIII & III & \multirow[t]{4}{*}{$\mathrm{a}, \mathrm{d}$} \\
\hline & & & J1 & 225 & 68 & $\mathrm{e}, \mathrm{f}, \mathrm{g}$ & $\mathrm{d}, \mathrm{e}$ & $\mathrm{b}, \mathrm{c}$ & $\mathrm{O}$ & I & $\mathrm{V}$ & III & \\
\hline & & & $\mathrm{J} 2$ & 76 & 67 & e,f,g & $\mathrm{d}, \mathrm{e}$ & $\mathrm{b}, \mathrm{c}$ & $\mathrm{O}$ & $\mathrm{I}$ & $\mathrm{V}$ & III & \\
\hline & & & J3 & 141 & 57 & $\mathrm{e}, \mathrm{f}, \mathrm{g}$ & $\mathrm{d}$ & $\mathrm{b}, \mathrm{c}$ & $\mathrm{O}$ & $\mathrm{I}$ & $\mathrm{V}$ & III & \\
\hline & thick and & & $\mathbf{S}$ & 333 & 35 & $\mathrm{~d}, \mathrm{f}$ & $\mathrm{e}$ & $\mathrm{a}$ & $\mathrm{O}$ & $\mathrm{I}$ & VIII & III & $\mathrm{a}$ \\
\hline TD-5 & thin bed- & +394 & J1 & 76 & 57 & $\mathrm{e}, \mathrm{f}, \mathrm{g}$ & $\mathrm{d}$ & $\mathrm{b}, \mathrm{c}$ & $\mathrm{O}$ & I & $\mathrm{V}$ & III & $\mathrm{b}$ \\
\hline & $\begin{array}{l}\text { ded lime- } \\
\text { stone }\end{array}$ & & $\mathrm{J} 2$ & 191 & 61 & $e, f, g$ & $\mathrm{~d}, \mathrm{e}$ & $b, c$ & $\mathrm{O}$ & I & V & III & $\mathrm{a}$ \\
\hline & thick & & $\mathbf{S}$ & 319 & 40 & $\mathrm{f}$ & $\mathrm{e}$ & $\mathrm{a}$ & $\mathrm{O}$ & $\mathrm{I}$ & VIII & III & \\
\hline TD-6 & bedded & +362 & J1 & 53 & 60 & $\mathrm{e}, \mathrm{f}, \mathrm{g}$ & $\mathrm{d}, \mathrm{e}$ & $\mathrm{b}, \mathrm{c}$ & $\mathrm{O}$ & $\mathrm{I}$ & $\mathrm{V}$ & III & $\mathrm{a}$ \\
\hline & limestone & & J2 & 204 & 60 & $e, f, g$ & $\mathrm{~d}, \mathrm{e}$ & $\mathrm{b}, \mathrm{c}$ & $\mathrm{O}$ & I & $\mathrm{V}$ & III & \\
\hline & & & $\mathbf{S}$ & 326 & 40 & $\mathrm{e}, \mathrm{f}, \mathrm{g}$ & $\mathrm{d}, \mathrm{e}$ & $\mathrm{a}$ & $\mathrm{O}$ & $\mathrm{I}$ & VIII & III & \\
\hline & $\begin{array}{l}\text { thick } \\
\text { bedded }\end{array}$ & & J1 & 93 & 80 & $e, f, g$ & $\mathrm{~d}, \mathrm{e}$ & $\mathrm{b}, \mathrm{c}$ & $\mathrm{O}$ & $\mathrm{I}$ & $\mathrm{V}$ & III & \\
\hline TD-7 & $\begin{array}{l}\text { bedded } \\
\text { limestone }\end{array}$ & +431 & $\mathrm{~J} 2$ & 193 & 72 & $\mathrm{e}, \mathrm{f}, \mathrm{g}$ & $\mathrm{d}, \mathrm{e}$ & $\mathrm{b}, \mathrm{c}$ & $\mathrm{O}$ & I & $\mathrm{V}$ & III & $\mathrm{a}$ \\
\hline & & & J3 & 140 & 83 & e,f,g & $\mathrm{d}, \mathrm{e}$ & $\mathrm{b}, \mathrm{c}$ & $\mathrm{O}$ & I & $\mathrm{V}$ & III & \\
\hline $\begin{array}{l}{ }^{1} \mathbf{S} \text { : bedd } \\
{ }^{2} \text { extreme } \\
\text { wide (600 } \\
{ }^{3} \text { very lo } \\
{ }^{4} \text { very tig } \\
\text { wide (2.5 } \\
\text { } \\
{ }^{5} \text { filling n } \\
{ }^{6} \text { fresh: I, } \\
\text { soil: VI } \\
{ }^{7} \text { I: rough } \\
\text { slickensic } \\
{ }^{8} \text { tight, d } \\
\text { free wate } \\
{ }^{9} \text { very lar } \\
(10<\mathrm{Jr}<3\end{array}$ & $\begin{array}{l}(<0.1 \mathrm{~mm}) \text { : a, } \\
10 \mathrm{~mm}) \text { : e, wi } \\
\text { terial: a, no fil } \\
\text { ightly weathe } \\
\text { tepped, II: sm } \\
\text {, undulating, } \\
\text { water flow n } \\
\text { resent: IV, se } \\
\text { blocks (Jr, jo } \\
\text { d. very small }\end{array}$ & $\begin{array}{l}\text { tight }(0 . \\
\text { le }(>10 \mathrm{~m} \\
\text { ling mate } \\
\text { red: II, } \mathrm{m} \\
\text { ooth, ste } \\
\text { VII: roug } \\
\text { possibl } \\
\text { page, dr } \\
\text { ints } / \mathrm{m}^{3}< \\
\text { blocks }\end{array}$ & $\begin{array}{l}-0.25 \mathrm{~mm}) \text { : } \\
\text { n): wide, } \mathrm{v} \\
\text { rial: b } \\
\text { oderately v } \\
\\
\text { ped, III: s } \\
\text { n, planar, } \\
\text { : I, dry, no } \\
\text { ps of wate } \\
\text {,0): a, larg } \\
\text { r>30): e }\end{array}$ & $\begin{array}{l}\text { b, partl } \\
\text { ery wid } \\
\text { veathere } \\
\text { ickensic } \\
\text { IIII: sm } \\
\text { evidenc } \\
\text { r, no co } \\
\text { e blocks }\end{array}$ & $\begin{array}{l}\text { ed, step } \\
\text { th, pla } \\
\text { of wa } \\
\text { tinuous } \\
(1<\mathrm{Jr}<\end{array}$ & $\begin{array}{l}\text { m): c, n } \\
.25-0.5 \\
\text { n): f, ex } \\
\text { ghly we } \\
\text { ged, IV: } \\
\text { har, IX: } \\
\text { er flow: } \\
\text { flow: V } \\
\text { ): } b \text {, me }\end{array}$ & $\begin{array}{l}\text { thered } \\
\text { rough, } \\
\text { slicken } \\
\text { II, dry, } \\
\text { contir } \\
\text { dium-s }\end{array}$ & $\begin{array}{l}\text { undul } \\
\text { sided, } \\
\text { evider }\end{array}$ & $\begin{array}{l}\text { ing, } \\
\text { lanar } \\
\text { e of }\end{array}$ & $\begin{array}{l}\text { high } \\
.50 \mathrm{~m} \\
\mathrm{~cm}):\end{array}$ & $\begin{array}{l}\text { thered: } \\
\text { th, und } \\
\text { ow: III, } \\
\text { I }\end{array}$ & derat & \\
\hline
\end{tabular}


Table 2 - Sliding potential and failure modes utilizing stereographic projections for each selected area.

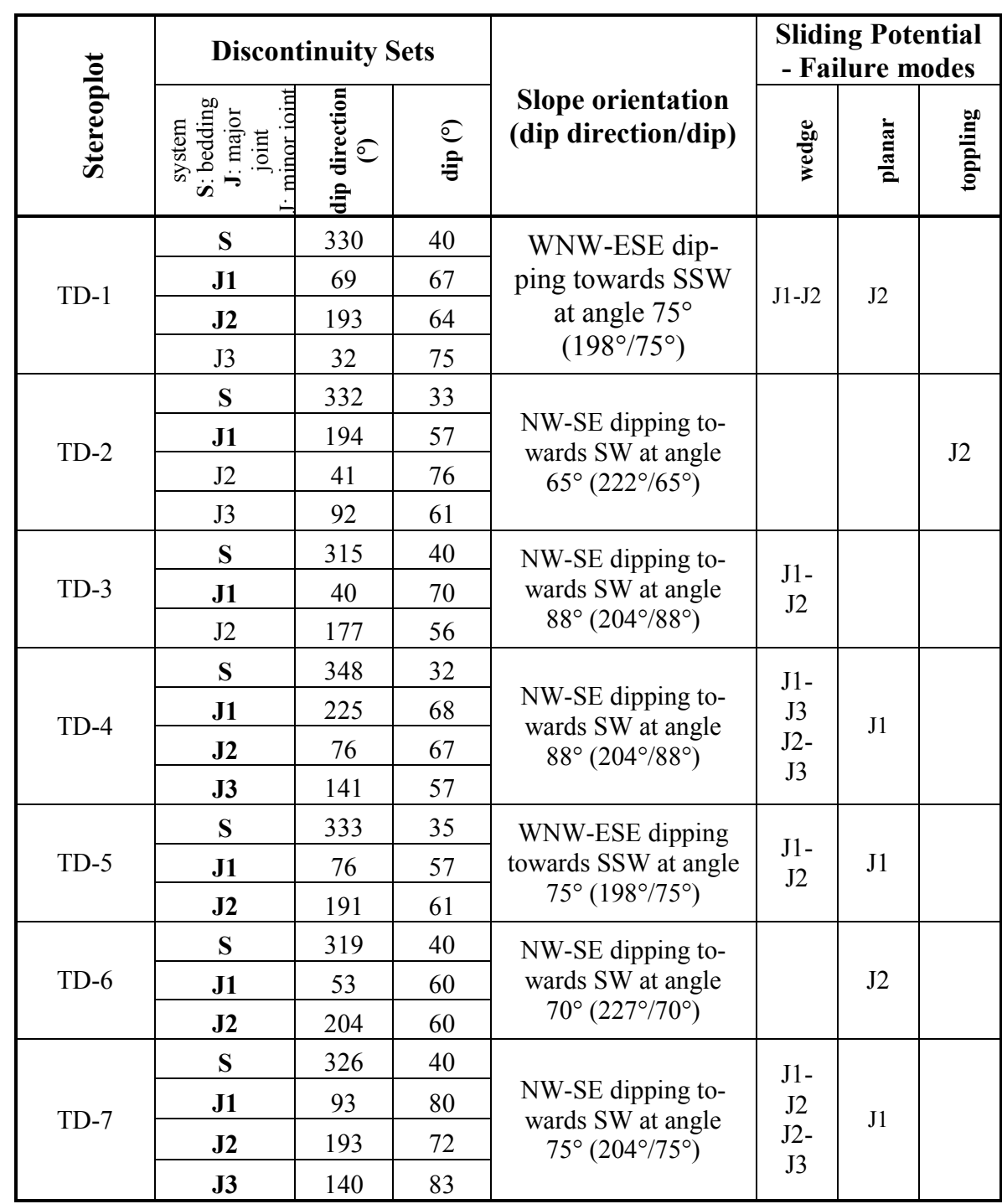

\section{Description of the Rock Mass Surrounding the Skete}

The cavern of the Skete is formed to the west by a rupture surface with dip direction $/ \operatorname{dip} 240^{\circ} / 90^{\circ}$, to the northwest by a major joint with dip direction/dip $326^{\circ} / 40^{\circ}$, and its roof follows the limestone bedding with dip direction/dip $320^{\circ} / 35^{\circ}$. The limestone rock mass that surrounds the Skete has been divided into seven sections (1-7). Each section includes a $2.50 \mathrm{~m}$ to $3.50 \mathrm{~m}$ thick rock mass segment, which is separated by its underlying one with a nearly vertical joint of high to very high persistence and NW-SE direction, dipping to the NE up to SW (dip direction/dip: $032^{\circ}$ $\left.212^{\circ} / 85^{\circ}-90^{\circ}\right)$. Each of the seven rock mass sections, according to its sequence number, superimposes parts of the previous section and partially covers them. Also, each section is subdivided into rock blocks (with codes: a,b,c,d,e...) which are demarcated by the limestone bedding and rock mass major joints (Figure 3). 


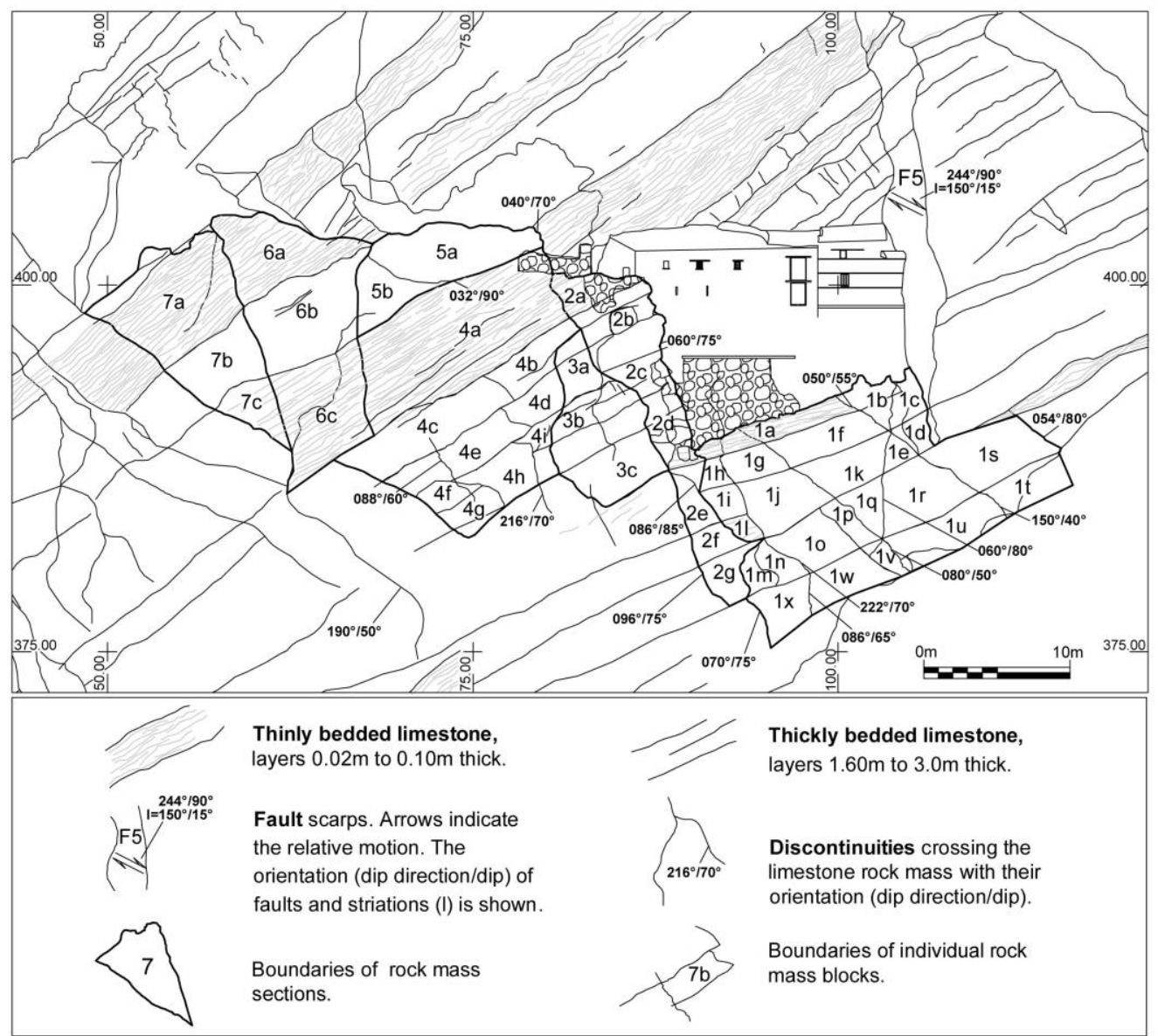

Figure 3 - Geological and tectonic map of the Skete's surrounding area.

Section 1 has dimensions (width $\mathrm{x}$ height) of $22.0 \mathrm{~m}$ by $13.0 \mathrm{~m}$, is located at the base of the sheer slope under the Skete, at elevation that ranges from $375 \mathrm{~m}$ to $391 \mathrm{~m}$, and its upper part is embedded in the Skete's foundations. It consists of four limestone layers, of thickness that ranges from $2.30 \mathrm{~m}$ to $3.80 \mathrm{~m}$ and orientation (dip direction/dip) $316^{\circ}-333^{\circ} / 35^{\circ}-45^{\circ}$. At its upper part a $1.30 \mathrm{~m}$ thick layer of thinly-bedded limestone is intercalated, having the same bedding dip. Three major joints are developed, which together with the bedding demarcate the rock blocks. Their orientations are $225^{\circ} / 68^{\circ}, 067^{\circ} / 76^{\circ}$, and $140^{\circ} / 57^{\circ}$. Section 1 is divided into 23 rock blocks, with dimensions that range from $3.40 \mathrm{~m} \times 2.50 \mathrm{~m} \times 1.80 \mathrm{~m}$ to $6.0 \mathrm{~m} \times 4.0 \mathrm{~m} \times 3.0 \mathrm{~m}$.

Section 2 has dimensions of $5.0 \mathrm{~m}$ (w) by $24.5 \mathrm{~m}(\mathrm{~h})$, is an elongate rock block that retains the western side of the Skete. It develops between elevations $378 \mathrm{~m}$ and $401 \mathrm{~m}$ and its upper part is embedded in the wall of the Skete's small courtyard. It comprises twelve limestone layers with orientation $326^{\circ}-332^{\circ} / 35^{\circ}-40^{\circ}$ and thickness of $1.10 \mathrm{~m}$ to $3.30 \mathrm{~m}$. At its upper part a $2.50 \mathrm{~m}$ thick layer of thinly-bedded limestone is intercalated, which maintains the same bedding dip. The eastern and western boundaries of this section are defined by two major joint sets with orientations $070^{\circ} / 75^{\circ}$ and $074^{\circ} / 70^{\circ}$, respectively. Apart from bedding, rock blocks are demarcated also by two major joint sets with orientations $077^{\circ} / 40^{\circ}$ and $177^{\circ} / 56^{\circ}$. Section 2 is divided into seven rock blocks with dimensions that range from $2.0 \mathrm{~m} \times 2.50 \mathrm{~m} \times 1.50 \mathrm{~m}$ to $5.0 \mathrm{~m} \times 4.50 \mathrm{~m} \times 2.50 \mathrm{~m}$.

Section 3 has dimensions of $12.0 \mathrm{~m}(\mathrm{w})$ by $7.0 \mathrm{~m}(\mathrm{~h})$ and is developed at the west side of the Skete, between $385 \mathrm{~m}$ and $397 \mathrm{~m}$ in elevation. It consists of six limestone layers, of thickness ranging from 
$1.0 \mathrm{~m}$ to $3.50 \mathrm{~m}$ and orientation $348^{\circ} / 35^{\circ}$. The major joints, which demarcate the section from the east and west, have orientations $216^{\circ} / 70^{\circ}$ and $060^{\circ} / 75^{\circ}$, respectively. Together with bedding, three major joint sets with orientations $225^{\circ} / 68^{\circ}, 076^{\circ} / 67^{\circ}$ and $141^{\circ} / 57^{\circ}$ divide this section into three rock blocks, with dimensions ranging from $3.80 \mathrm{~m} \times 2.50 \mathrm{~m} \times 2.50 \mathrm{~m}$ to $6.0 \mathrm{~m} \times 3.50 \mathrm{~m} \times 2.50 \mathrm{~m}$.

Section 4 has dimensions of $13.50 \mathrm{~m}(\mathrm{w})$ by $19.0 \mathrm{~m}(\mathrm{~h})$ and is located to the west of the Skete, between $383 \mathrm{~m}$ and $402 \mathrm{~m}$ in elevation. Its upper part is embedded in the wall of the Skete's courtyard. It comprises seven limestone layers of thickness ranging from $1.50 \mathrm{~m}$ to $2.50 \mathrm{~m}$ and orientation $315^{\circ} / 40^{\circ}$. At its upper part a $7.0 \mathrm{~m}$ thick layer of thinly-bedded limestone is intercalated, having the same bedding dip. The two major joint sets which together with the bedding define the rock blocks have orientations $040^{\circ} / 77^{\circ}$ and $177^{\circ} / 56^{\circ}$. Section 4 is divided into nine rock blocks with dimensions between $2.60 \mathrm{~m} \times 2.20 \mathrm{~m} \times 2.0 \mathrm{~m}$ and $11.0 \mathrm{~m} \times 3.50 \mathrm{~m} \times 2.50 \mathrm{~m}$.

Section 5 has dimensions of $12.0 \mathrm{~m}(\mathrm{w})$ by $8.0 \mathrm{~m}(\mathrm{~h})$ and also develops to the west of the Skete at elevation ranging from $396 \mathrm{~m}$ to $404 \mathrm{~m}$. Two major joint sets with orientations $040^{\circ} / 77^{\circ}$ and $177^{\circ} / 56^{\circ}$ define the rock blocks. This rock mass section is divided into two sizeable rock blocks with dimensions ranging from $6.0 \mathrm{~m} \times 5.0 \mathrm{~m} \times 3.0 \mathrm{~m}$ to $12.0 \mathrm{~m} \times 4.0 \mathrm{~m} \times 3.0 \mathrm{~m}$.

Section 6 has dimensions of $11.0 \mathrm{~m}(\mathrm{w})$ by $19.0 \mathrm{~m}(\mathrm{~h})$ and is located to the west of the Skete at elevation ranging from $386 \mathrm{~m}$ to $405 \mathrm{~m}$. It consists of one limestone layer $7.50 \mathrm{~m}$ thick and with orientation $315^{\circ} / 40^{\circ}$, lying between two layers of thinly-bedded limestone $6.0 \mathrm{~m}$ and $7.0 \mathrm{~m}$ thick, respectively, having the same dip of bedding. The two major joints that demarcate the rock block boundaries have orientations $040^{\circ} / 77^{\circ}$ and $177^{\circ} / 56^{\circ}$. The rock mass section is divided into three rock blocks of dimensions $7.0 \mathrm{~m} \times 6.0 \mathrm{~m} \times 3.0 \mathrm{~m}$.

Finally, section 7 has dimensions $15.0 \mathrm{~m}(\mathrm{w})$ by $11.0 \mathrm{~m}(\mathrm{~h})$ and is developed to the west of the Skete, between $389 \mathrm{~m}$ and $404 \mathrm{~m}$ in elevation. It comprises a $3.50 \mathrm{~m}$ thick limestone layer, with an orientation $315^{\circ} / 40^{\circ}$, lying between two layers of thinly-bedded limestone, $6.0 \mathrm{~m}$ and $7.0 \mathrm{~m}$ thick, respectively, that maintain the same bedding dip. The main joints, which define the boundaries of the rock blocks, are classified into two major joint sets with orientations $040^{\circ} / 77^{\circ}$ and $177^{\circ} / 56^{\circ}$. The section is divided into three rock blocks with dimensions ranging from $5.50 \mathrm{~m} \times 4.0 \mathrm{~m} \times 3.0 \mathrm{~m}$ to $8.50 \mathrm{~m} \times 6.0 \mathrm{~m} \times 3.0 \mathrm{~m}$.

\section{Evaluation of Rock Mass Stability}

Under the conditions hitherto prevailing, both major sections and sub-sections of the limestone escarpment, have demonstrated a stable behavior. The future water level rise, up to the entrance level of the Skete, due to the filling of the Ilarion Dam's reservoir (estimated max. water level: $+398.50 \mathrm{~m}$ ), will impose an initial increase, and subsequent variations of water pressures in the rock mass discontinuities. The evaluation of the rock mass stability, due to water induced loads, was therefore required.

Stability of the limestone slope was checked against potential wedge and plane failure, utilizing Swedge (v. 5.010) and RocPlane (v. 2.029) programs (Rocscience), respectively, with assumed shear strength of discontinuities: $c=0, \varphi=35^{\circ}$. The following cases were examined:

a. Static loads, with required factor of safety (F.O.S. A1) $>1.50$

b. The worst-case scenario for water-induced loads assumed a sudden drop of water level, without any dissipation of water pressures in rock fissures, resulting in the development of pressures corresponding to $100 \%$ water filled fissures, with required F.O.S. A2 >1.30

c. Furthermore, the extreme case of seismic loading with simultaneous full hydrostatic pressures in rock fissures was also examined, with required F.O.S. A3 $>1.00$

All sections and subsections were checked, based on the results of the microtectonic analyses. The results of unsupported sections are presented in Table 3.

$\underline{\text { XLVII, No } 3-1787}$ 
Table 3 - Stability analysis of unsupported sections.

\begin{tabular}{|c|c|c|c|c|c|c|c|}
\hline \multirow{2}{*}{ No. } & \multirow{2}{*}{ Wedge } & \multirow{2}{*}{ Plane } & \multicolumn{3}{|c|}{ Factors of Safety } & \multirow{2}{*}{$\begin{array}{c}\text { Wedge } \\
\text { weight (tn) }\end{array}$} & \multirow{2}{*}{$\begin{array}{c}\text { Weight } \\
\text { per m (tn) }\end{array}$} \\
\hline & & & A1 & A2 & A3 & & \\
\hline \multicolumn{8}{|c|}{ Section 1: Subsections 1a to $1 x$} \\
\hline 1 & $\mathrm{~J} 1-\mathrm{J} 2$ & - & 0.34 & 0.00 & 0.00 & 243.75 & - \\
\hline 2 & S-J2 & - & 2.33 & 1.27 & 0.98 & 1733.25 & - \\
\hline 3 & - & $\mathrm{J} 2$ & 0.34 & 0.22 & 0.14 & - & 34.11 \\
\hline \multicolumn{8}{|c|}{ Section 2: Subsections 2a to $2 \mathrm{~g}$} \\
\hline 1 & J1-J2 & - & 0.47 & 0.00 & 0.00 & 0.7 & - \\
\hline 2 & S-J2 & - & 2.46 & 1.88 & 1.28 & 6.5 & - \\
\hline \multicolumn{8}{|c|}{ Section 3: Subsections 3a to 3c } \\
\hline 1 & $\mathrm{~J} 1-\mathrm{J} 2$ & - & 2.38 & 1.70 & 1.22 & 17.4 & - \\
\hline 2 & $\mathrm{~J} 1-\mathrm{J} 3$ & - & 0.62 & 0.26 & 0.18 & 27.3 & - \\
\hline 3 & $\mathrm{~J} 2-\mathrm{J} 3$ & - & 0.45 & 0.00 & 0.00 & 6.7 & - \\
\hline \multicolumn{8}{|c|}{ Section 4: Subsections 4a, 4b, 4d, 4h and 4i } \\
\hline 1 & $\mathrm{~J} 1-\mathrm{J} 2$ & - & 0.47 & 0.00 & 0.00 & 2.0 & - \\
\hline 2 & S-J2 & - & 2.56 & 1.95 & 1.33 & 17.8 & - \\
\hline
\end{tabular}

The above-presented results of the stability analyses of unsupported sections demonstrate the necessity of adopting appropriate support measures to increase stability. In order to achieve the adequate factors of safety, appropriate numbers of $6 \mathrm{~m}$ long rock anchors, of $16 \mathrm{tn}$ working load each, are adopted. The results of supported sections are presented in Table 4.

Table 4 - Stability analysis of supported sections.

\begin{tabular}{|c|c|c|c|c|c|c|c|}
\hline \multirow{2}{*}{ No. } & \multirow{2}{*}{ Wedge } & \multirow{2}{*}{ Plane } & \multicolumn{3}{|c|}{ Factors of Safety } & \multirow{2}{*}{$\begin{array}{c}\text { Wedge } \\
\text { weight (tn) }\end{array}$} & \multirow{2}{*}{$\begin{array}{c}\text { Weight } \\
\text { per m (tn) }\end{array}$} \\
\hline & & & $\mathbf{A 1}$ & $\mathbf{A 2}$ & $\mathbf{A 3}$ & & \\
\hline \multicolumn{8}{|c|}{ Section 1: Subsections 1a to $1 \mathrm{x}$ with 33 anchors } \\
\hline 1 & $\mathrm{~J} 1-\mathrm{J} 2$ & - & 6.48 & 2.50 & 1.70 & 243.75 & - \\
\hline 2 & S-J2 & - & 3.24 & 1.85 & 1.22 & 1733.25 & - \\
\hline 3 & - & $\mathrm{J} 2$ & 1.50 & 1.32 & 1.04 & - & 34.11 \\
\hline \multicolumn{8}{|c|}{ Section 2: Subsections 2a to $2 \mathrm{~g}$ with 13 anchors } \\
\hline 1 & $\mathrm{~J} 1-\mathrm{J} 2$ & - & 25.64 & 8.27 & 7.84 & 0.7 & - \\
\hline \multicolumn{8}{|c|}{ Section 3: Subsections 3a to $3 \mathrm{c}$ with 8 anchors } \\
\hline 2 & $\mathrm{~J} 1-\mathrm{J} 3$ & - & 3.75 & 2.83 & 2.10 & 27.3 & - \\
\hline 3 & $\mathrm{~J} 2-\mathrm{J} 3$ & - & 4.72 & 1.49 & 1.23 & 6.7 & - \\
\hline \multicolumn{8}{|c|}{ Section 4: Subsections 4a, 4b, 4d, 4h and $4 \mathrm{i}$ with 7 anchors } \\
\hline 1 & $\mathrm{~J} 1-\mathrm{J} 2$ & - & 9.64 & 3.01 & 2.86 & 2.0 & - \\
\hline
\end{tabular}

The above-presented results of the stability analyses of supported sections demonstrate the adequacy of the proposed number of anchors for each corresponding section.

\section{Support Measures}

Based on restrictions on monument preservation, the adoption of measures such as the application of shotcrete or concrete or wire mesh installation is excluded. The proposed solution comprises three stages of installation of support measures, namely, installation of temporary rock bolts for the pre-strengthening of the rock mass, followed by the execution of grouting and finally 
installation of permanent active rock anchors (Figure 4, Figure 5). The proposed measures intend to increase the cohesion of the rock mass by means of grouting rock discontinuities and to support potentially unstable rock blocks by means of active permanent rock anchors.

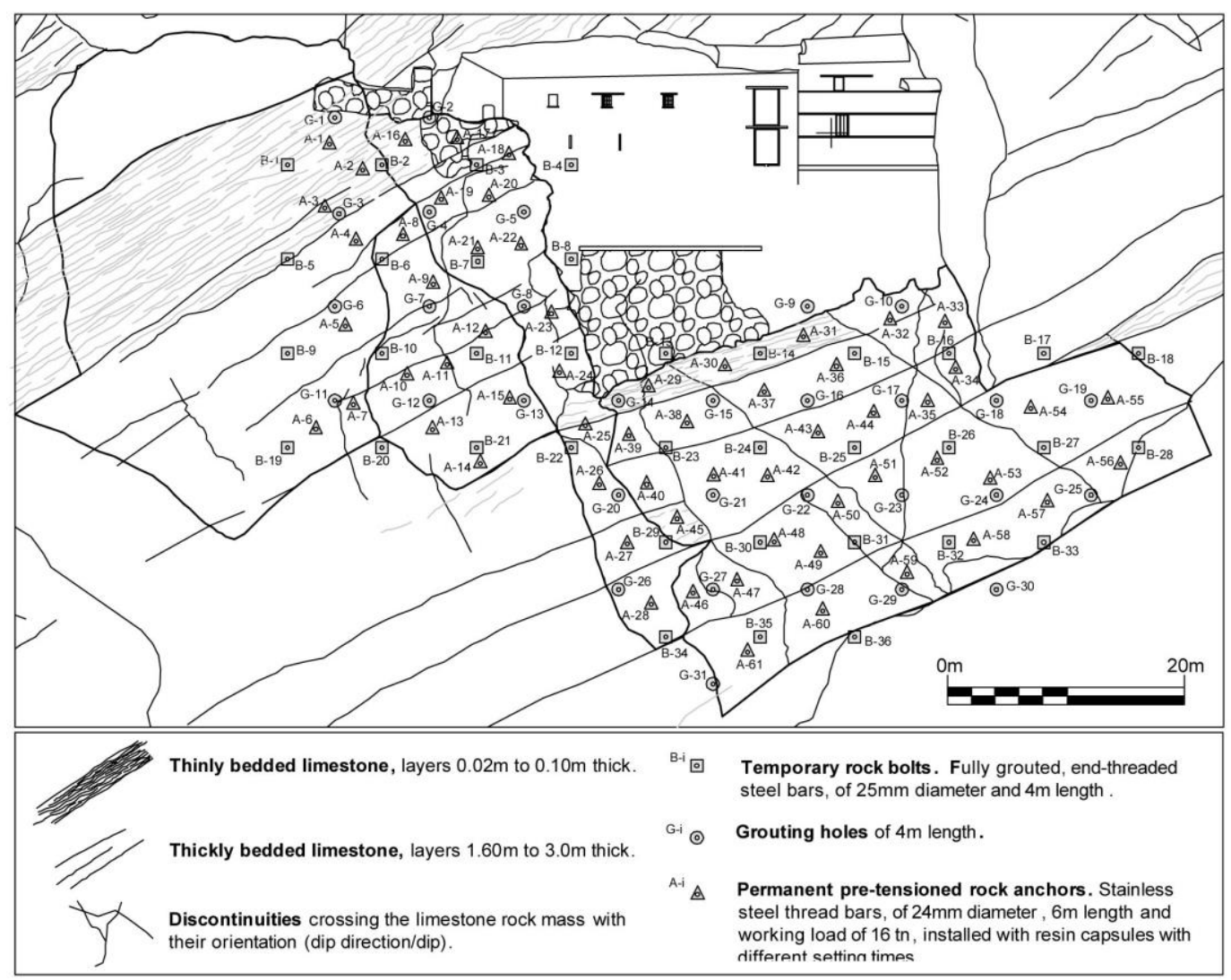

Figure 4 - Slope face of the Skete's surrounding area, indicating the position of the support measures.

Temporary rock bolts, will be installed for the pre-strengthening of the rock mass, in order to avoid any failures in weaker parts of the slope as a result of the applied pressures during subsequent grouting works. The temporary rock bolts are fully grouted, end-threaded steel bars, of $25 \mathrm{~mm}$ diameter and $4 \mathrm{~m}$ length, applied in an indicative $4 \mathrm{~m} \times 4 \mathrm{~m}$ pattern (Figure 4, Figure 5). Grouting holes of $4 \mathrm{~m}$ length will be drilled in a $4 \mathrm{~m} \times 4 \mathrm{~m}$ pattern on the entire slope area, in order to increase the cohesion of the rock mass, combined with targeted grouting in open discontinuities. Cement grout of a water to cement ratio of 1:1 will be initially injected and according to observed absorptions it may vary up to $0.5: 1$ (w:c). The grout mix will also include $1 \%$ bentonite (Figures 4 , Figure 5).

Permanent rock anchors of appropriate length and of adequate capacity will be used for the stabilization of all potentially unstable blocks. Selection of location and length of permanent rock anchors was made in order to ensure stability of all sections and subsections. Therefore, the application of at least one anchor per section and subsection was considered necessary. The number, the location, the length and the angle of installation of the permanent rock anchors were selected in order to ensure adequate factors of safety, against plane and wedge failures along discontinuities, for various combinations of static, water and earthquake loading combinations, of both subsections and major sections of the rock mass. 
The permanent rock anchors are end-anchored, stainless steel thread bars, of $24 \mathrm{~mm}$ diameter and $4 \mathrm{~m}$ to $6 \mathrm{~m}$ lengths, with working loads of $16 \mathrm{tn}$. The anchors are installed with resin capsules with different setting times, thus enabling quick installation and anchor pre-tensioning. The anchors will be pre-tensioned in the working load of 16 tn (Figure 6).

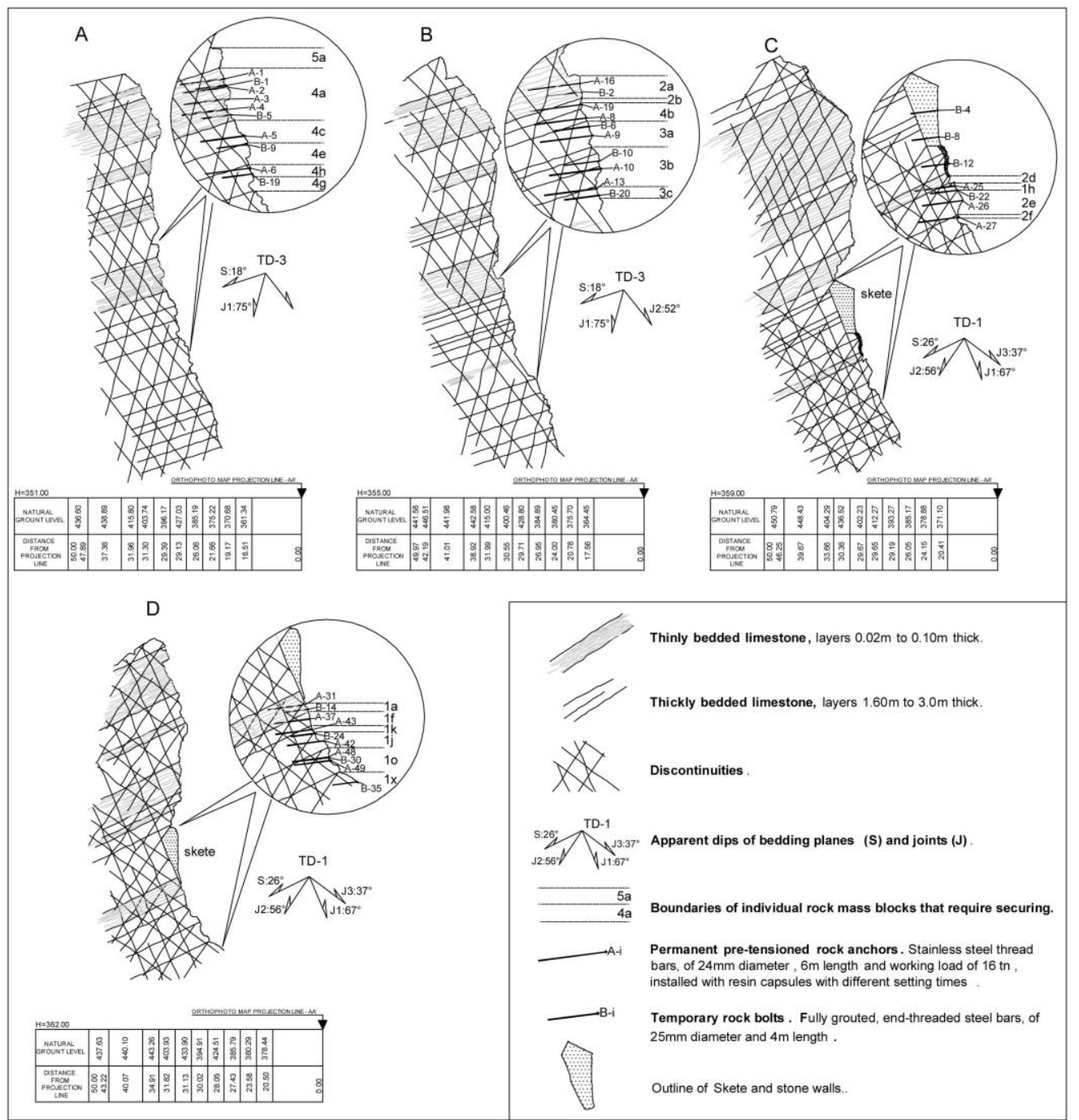

Figure 5 - Geological cross sections indicating the position of the support measures.

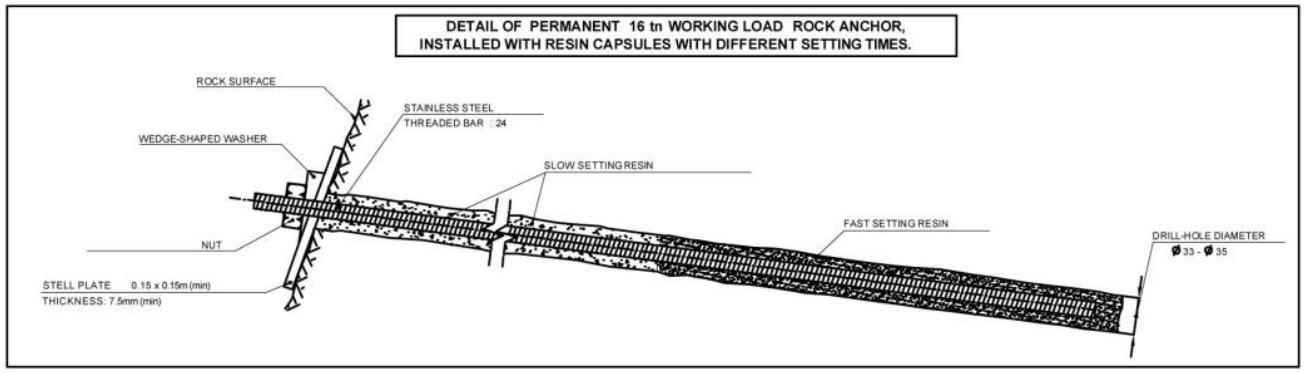

Figure 6 - Drawing of a Permanent rock anchor system.

$\underline{\text { XLVII, No } 3-1790}$ 


\section{Conclusions}

Filling of the Ilarion Dam's reservoir will result in the water level rise up to the entrance level of the Skete of Osios Nikanoras and water level fluctuations. Therefore, the behavior of the surrounding rock mass before and after the rise of water level was investigated. Due to the difficulty of accessing the Christian monument, besides the conventional geological and geotechnical techniques, the terrestrial laser scanning method was employed, so that a complete engineering geological rock mass evaluation and analysis of the instability mechanisms to be achieved.

The limestone rock mass was divided into discrete sections and these were subdivided into individual rock blocks, as defined by the rock mass discontinuities. The geomechanical analysis of rock mass has demonstrated a stable behavior under dry conditions that seems to change in a wet environment and it is burdened with seismic loading.

The adoption of support measures in three stages of installation, namely, installation of temporary rock bolts for the pre-strengthening of the rock mass, followed by the execution of grouting and finally installation of permanent active rock anchors. Selection of the above measures is in accordance to the restrictions regarding the monument and historic landscape preservation and aims at the ensuring of the rock mass stability against unfavorable future conditions.

\section{References}

EAK 2000. Greek Antiseismic Code: Ministry of Public Works of Greece, FEK 2184 B'/20-121999.

Eurocode 7 1995. European standards for design of geotechnical projects.

Eurocode 8 1998. European standards for earthquake design.

Goodman R.E. 1976. Methods of Geological Engineering in Discontinuous Rocks. West Publishing, San Francisco.

Hocking G. 1976. A method for distinguishing between single and double plane sliding of tetrahedral wedges, Int. J. Rock Mech. Min. Sci. Geomech. Abstr. 13, 225-226.

Hoek E., Bray J.W. 1981. Rock Slope Engineering Institution of Mining and Metallurgy, London.

ISRM Suggested Methods, 1981., in Brown, E.T. (ed), Rock Characterization Testing \& Monitoring, Pergamon Press, 211pp.

Karapantelakis K., Emmanoyhlidis G., Karagiannaki V. and Minopetros Ch. 2008. Ilarion Dam: The most important geological and geotechnical problems that have been faced during the designs as well as the construction. Proc. of the $1^{\text {st }}$ Hellenic Congress on Big Dams, Larisa, 13-18 November 2008, 1-13.

Katsikatsos G.X. 1992. Geology of Greece. Athens: Katsikatsos, 451pp. (in Greek).

Markland J.T. 1972. A useful technique for estimating the stability of rock slopes when the rigid wedge sliding type of failure is expected. Imp. Coll. Rock Mech. Res. Rep. 19, 10.

Matherson G.D., 1988. The collection and use of field discontinuity data in rock slope design. Q. J. Eng. Geol. 22, 19-30.

Papazachos, B.C. and Papazachou, K., 1989. The Earthquakes of Greece. Ziti Editions, Thessaloniki, 356pp. (in Greek).

Rockscience Inc., 2005. Phase2 6.0, A 2-D FE elastoplastic Code for geotechnical applications. Toronto, Ontario, Canada.

Stamatis A., 1987. Geological map of Greece: Deskati sheet (scale 1:50.000), IGME Publications, Athens.

Vérgely P., 1984. Tectonique des ophiolites dans les Hellénides internes (déformations, métamorphismes et phénomènes sédimentaires). Conséquences sur l'évolution des régions téthysiennes occidentales, Thèse, sciences, Univ. Paris Sud, Orsay, pp. 649. 